Yehorova Valentyna,

$\mathrm{PhD}$ (Law Sciences), Associate Professor, National Technical University of Ukraine «Igor Sikorsky Kyiv Polytechnic Institute», 37, Prosp. Peremohy, Kyiv, 03056, Ukraine ORCID: 0000-0001-8485-430X

Researcher ID: I-6210-2017

\title{
EUROPEAN INTEGRATION OF UKRAINE IN NATIONAL LEGISLATION
}

The article is devoted to the European integration of our Ukrainian legislation into the legislation of the European Union countries, taking place in Ukraine on the way towards the EU membership.

Keywords: European Union; European integration; Convention; NATO.

\section{Сгорова Валентина. Свроінтеграція Украӥни в національному зако- нодавстві.}

Стаття присвячена євроінтеграчії нашого Українського законодавства до законодавства країн Європейського союзу, що відбувається в Украйні на шляху до членства в $C C$.

Ключові слова: Європейський союз; Європейська інтеграчія; Конвениія; HATO.

Research rationale. The research in this context is particularly important for the legal analysis of achievements and developments, as well as for monitoring the next steps of the Ukrainian state in the process of accession to the EU, thus for strengthening the democratic foundations and the rule of law.

Problem definition. The European integration processes and Ukraine's membership in the European Union are the main tools for embodiment of the national interests, building the rule-of-law and democratic state, strengthening existing and introducing new mechanisms of functioning of civil society in Ukraine in accordance with the European model. Ukraine's accession to the EU is the key to further strengthening of domestic positions in the international stage.

Analysis of recent researches and publications. Analysing the speed of the historical and political changes that have taken place in the last decades in the European community, it is worth noting the need to re-evaluate ideas and positions in the Ukrainian and European relations.

Many national scientists and politicians, whose filed of scientific interest include this subject, are engaged in scientific researches concerning the stages of 
Ukraine's movement towards the European community, its state policy in the field of European integration, as well as comprehensive studies of political and economic influences on Ukrainian society in connection with our country's accession to the European community.

The European integration of Ukraine is considered to be a separate element of our country's foreign policy activity, that is why the analysis of its steps in this direction becomes relevant and interesting as an object of scientific research.

Task definition. The task definition is to study the status, prospects and legal implications of Ukraine's membership in the European Union as a key to building civil society, as well as to overcome the problems encountered during the integration processes (Website of the European Court of Human Rights).

Basic material presentation. One of the next steps aimed at bringing Ukraine closer to the European standards was signing of the political part of the Association Agreement with the European Union on March 21, 2014.

Establishment of a pan-European security structure using the UN, OSCE, NATO, EU mechanism has become a priority. Ukraine has chosen a course for European and Euro-Atlantic integration, which has become a decisive factor in bringing foreign policy into practice. The Ukrainian state aims to become the leading country in the world, the centre of integration of Eastern and Western Europe. A wellelaborated ethnopolitics of an independent Ukraine contributes to a certain degree to a dialogue at all levels, including the opportunity to defend the interests of Ukrainians and the Ukrainian diaspora abroad (Association Agreement between Ukraine, of the one part, and the European Union and its Member States, of the other part).

Thus, signing of the Association Agreement with the European Union made it incumbent on Ukraine to implement the European standards in ensuring the principle of respect for human rights and freedoms, as well as the right to a fair trial as guaranteed by the Convention for the Protection of Human Rights and Fundamental Freedoms. Obviously, its implementation is not possible without effective application in the national law-making and enforcement activities of the ECHR, because it is known that «the rules of the Convention operate as interpreted by the European Court of Human Rights» (O. P. Kuchunska, T. I. Fyley, P. V. Barannik, 2013).

Choosing the European development vector for Ukraine means moving towards the European civilization model, which implies a complex democratic transition to a politically organized, responsible society of a new quality, which gradually increases the level of business activity and political participation of citizens, ensuring their rights and freedoms, forming a new structure of social space. All these qualitative changes in the structure and content of the civil society inevitably determine changes in the form and content of the state, especially in the system of public administration, which implies, first of all, a radical change in the format of communication between the state and its citizens. And the basis for such a new 'format' should be the formation of an effective and efficient system of public administration, adequate to Ukrainian realities 
and global trends. In the Western state governing, philosophical and historical tradition, the problems of understanding and conceptualization of the issues of public administration, in spite of the relatively comprehensive development of these issues, the systemic features of modernization of the public administration system, depending on the national specificity of social transformations, had not been paid sufficient attention. That is why these issues in the science of public administration require further comprehensive study.

Conclusion. Thus, summarizing the above, we can conclude that the system of relations between the European Union and the civil society of Ukraine already gives some positive developments in the context of ensuring democratic and European development of the country.

The European Union, by its own example, demonstrates the importance of the civil society interaction with the authorities. A full-fledged civil society is possible due to development of the rule of law. Ukraine's accession to the EU will allow the Ukrainian society to move on to the next step towards promotion of the European values of functioning of civil society, namely: development and implementation of the rule of law is possible due to restructuring of the legislation, which must be mandatory for all; protection of the violated human and citizen's rights and freedoms; overcoming corruption processes in accordance with the internationally recognized regulations. The EU proposes in its foreign policy promotion of the relevant values in the field of strengthening the civil society, which is one of the important tasks on the way to its membership (Bases of cooperation of Ukraine with the European Court of Justice (official information of the Representation of Ukraine in the European Court of Justice)).

Many years of the EU experience are of great importance for Ukraine, especially in today's context, when there is an urgent need to stabilize the development of the country as a whole. Due to this, the civil society is revitalized and, as a result, a constructive dialogue between the authorities and society is established. Most Ukrainian citizens support the need for the EU integration. This is due to the relevance of the following aspects:

1) compulsory implementation of the EU-Ukraine Association Agreement is today an important tool through which it is possible to implement politically and nationally required reforms;

2) domestic society and public authorities largely understand the importance of fulfilling their commitments as proof for the European Union of a real desire for the EU integration;

3) owing to the positive results of implementation of the agreement, the EU is able to take counter-steps and optimize its own relations with Ukraine (X. Mashtalir, S. Leskiv, 2017).

Thus, without dwelling on the achievements in the field of the European integration in Ukraine, we would like to emphasize that there is a chance to carry out deep reforms in the field of building and strengthening the civil society of the European model. 
For Ukraine, the European integration is a way of modernizing the economy, overcoming technological backwardness, attracting foreign investment and new technologies, creating new jobs, enhancing the competitiveness of domestic producers, entering the world markets, especially the EU market. As an integral part of Europe, Ukraine is focusing on the current model of socio-economic development in the leading European countries.

The political benefits of Ukraine's integration into the EU are linked to the creation of robust mechanisms for political stability, democracy and security. Getting closer to the EU is a guarantee and meeting its requirements is a tool for building democratic institutions in Ukraine. In addition, the EU membership will open the way to the collective structures of the common security of the European Union, will provide more effective coordination of actions with the European countries in the field of export control and non-proliferation of weapons of mass destruction, will allow to intensify cooperation in the fight against terrorism, organized crime, smuggling, smuggling drug business, etc.

The European choice of Ukraine opens up new prospects for cooperation with the developed countries of the continent, provides opportunities for economic development, strengthening Ukraine's position in the world system of international relations. This is the best way to embody the national interests.

\section{REFERENCES}

1. Kuchunska Oksana Petrivna. Pruncipu kruminalnogo provadgennya u svitli praktuku Evropeyskogo sudu z prav lyudunu (Principles of criminal proceedings in the light of the case law of the European Court of Human Rights) (Tekst) : monografiya / O. P. Kuchunska, T. I. Fyley, P. V. Barannik. - Nigun : AspektPoligraf, 2013. - 224 p.

Retrieved from http://korolenko.kharkov.com/cgibin/wcatalog/irbis

2. Sayt Evropeyskogo sudy z prav lyudunu (Website of the European Court of Human Rights) Retrieved from: http://www.echr.coe.int/Pages/home.aspx?p=home

3. Ugoda pro asaciaciyu mig Ukrainoyu, $\mathrm{z}$ odniej storoni, ta Evropeyskim Soyuzom I yogo Dergavami - Chlenami, z inshoi storoni (Association Agreement between Ukraine, of the one part, and the European Union and its Member States, of the other part): Retrieved from: http://www.kmu.gov.ua/docs/Agreement/AA_Body_text.pdf

4. X. Mashtalir, S. Leskiv // Integracsya Ukrainu do Evropeyskogo soyuzu yak osnova dlya rozbudovi gromadyanskogo suspilstva (Integration of Ukraine into the European Union as a basis for building civil society) // Pidpruemstvo, gospodarstvo i Pravo - 6/2017. - P. 163-169.

5. Zasadi spivrobitnetstva Ukraini z Evropeiskim Souzom (oficiyna informaciya predstavnictva Ukrainu u Evropeiskomy Soyuzi) (Bases of cooperation of Ukraine with the European Court of Justice (official information of the Representation of Ukraine in the European Court of Justice)) Retrieved from http://www.ukraineeu.mfa.gov.ua/eu/ua/556.htm. 